\title{
STRATEGI COMPETITIVE ADVANTAGE UNTUK MEMBANGUN CITY BRANDING KOTA BATU SEBAGAI KOTA WISATA
}

\author{
Uyunur Rochmawati Miladiyah \\ Slamet \\ FakultasEkonomi UIN Maulana Malik Ibrahim Malang \\ Jl. Gajayana No. 50 Malang
}

\begin{abstract}
Globalization led to tough competition among cities around the world to win the competition to attract visitors and increase investment. Therefore, not only the company, the cities are also struggling to create uniqueness to gain an advantage in competition. It is very important to communicate the competitive advantages owned by these cities to the public and all parties to ensure the achievement of objectives. City branding is a method used to re-brand the city as identification which is expected to reflect the advantages as well as its uniqueness. Therefore, in 2013 Shining Batu was introduced as a city brand wich expected to be reflect the competitive advantage of Batu City. The purpose of this study is to reveal aspects of the competitive advantages Batu City; strategies that are used in communicating it; as well as how big the impact of the communication strategy for the visitors Batu City. The paradigm of this research is qualitatively by case study design. Data were obtained by interview and documentation. The results showed that the Batu City has three interrelated aspects superior to one another that supports the creation of competitive advantages: geographic and agricultural sectors are packed in the development of the tourism sector. At the same time, the government developed the program as a means of communicating Shining Batu and reflects the benefits of the city to the public. Shining Batu communicated through various forms of promotion that utilizes a wide variety of communication tools; a variety of Tour Package; and held aa variety of routine and incidental events. Questionnaire showed that aim to dominate the number of respondents traveled, which consists of a visitor, where recreational tourist attractions types over a favorite choice than any natural attractions. Hotel is a top choice for a place to stay. Most visitors make a visit to Batu City more than once.
\end{abstract}

Keywords: competitive advantage, city branding

Pada pertengahan tahun 1990'an, merek tidak hanya diaplikasikan pada produk (Gardyn, 2002), tetapi juga berlaku untuk jasa, tempat, kota, dan lain sebagainya. Hal ini didukung oleh Freire (2007) yang menjelaskan bahwa dewasa ini bukan hanya produk dan jasa yang fokus pada identitasnya dengan mengembangkan sistem brand management, banyak tempat atau lokasi yang juga menerapkan pengembangan semacam sistem brand management.Merujuk Moilanen \& Rainisto (2009), saat ini fenomena branding juga digunakan untuk daerah, kota, maupun negara. Seperti Kota Batu yang memiliki brand sebagai Kota Wisata, sebab citra Kota Batu di kalangan masyarakat luas adalah sebuah kota sejuk yang memiliki banyak tempat pariwisata dengan apel sebagai ciri khasnya. Mengenai penciptaan citra, Botha (1999) mengatakan harus didasari pada apa yang sudah ada di pikiran turis. Merujuk Blain, et al. (2005), janji yang tersirat dalam sebuah merek tujuan wisata sangatlah penting, sebagaimana organisasi jasa lainnya, jika janji tersebut tidak bisa tersampaikan, pengunjung akan kecewa. Kota Batu juga pernah dijuluki sebagai 'De Klei Switzerland' atau Swiss Kecil di Pulau Jawa. Selain itu, Batu juga dikenal sebagai kawasan agropolitan, sehingga mendapat julukan 'Kota Agropolitan' (wikipedia, 2013).

Kota Batu merupakan salah satu kota yang baru terbentuk pada tahun 2001 sebagai pecahan dari Kabupaten Malang. Merujuk Profil Kabupaten/Kota Batu (Andianto, et al., t.t) Kota Batu sebelumnya merupakan bagian dari Sub Satuan Wilayah Pengembangan 1 (SSWP 1) Malang Utara. Berdasarkan situs resmi Kota Batu (Kota Wisata Batu, 2011) pada tahun 2009 kunjungan wisatawan ke objek wisata kota Batu secara keseluruhan mengalami kenaikan. Didominasi oleh kunjungan wisatawan pada Taman Rekreasi Selecta sebesar 44\%, disusul oleh Jatim Park sebesar 
$30 \%$, lalu pemandian air panas Cangar $11 \%$, BNS yang saat itu terhitung masih muda sebesar $7 \%$, hingga Kusuma Agrowisata sebesar 6\% dari keseluruhan wisatawan yang datang ke kota Batu.

Kota Batu juga memiliki keunikan dan ciri khasnya sendiri. Hal ini tentunya mempengaruhi jumlah kunjungan wisatawan yang semakin meningkat dari tahun ke tahun. Apel merupakan ciri khas Kota Batu yang telah diakui oleh masyarakat luas. Sejak tahun 1960, menurut Sutopo (2011), tanaman apel sudah banyak ditanam di Kota Batu untuk menggantikan tanaman jeruk yang saat itu banyak mati diserang penyakit. Sehingga, sampai saat ini, Kota Batu menjadi kota Kawasan Agropolitan. Selain itu, Kota Batu juga terkenal dengan tempat-tempat bersejarah, Menone (2011) mencatat sejak abad ke-10, wilayah Batu telah dikenal sebagai tempat peristirahatan bagi kalangan keluarga kerajaan. Oleh sebab itu, hingga sekarang Kota Batu terkenal dengan tempat-tempat bersejarahnya, salah satunya adalah kawasan Wisata Songgoriti yang terdapat di dalamnya peninggalan bersejarah Candi Supo.

Terlebih lagi, Puspitarini (2014) menyebutkan bahwa Institut Teknologi Sepuluh Nopember (ITS) Surabaya berencana untuk mengembangkan transportasi alternatif kereta gantung, yang merupakan pertama kalinya di Indonesia, untuk Kota Batu yang nantinya kereta ini dapat menjadi ikon baru untuk Kota Batu.

Dengan pesatnya pertumbuhan sektor tujuan wisata, sebuah kota akan terus berusaha meningkatkan angka kunjungan turis domestik maupun mancanegara (Ardialisa, et al., 2012). Demikan halnya dengan Kota Batu. Kota Batu perlu membangun competitive advantage (keunggulan kompetitif), terutama dalam bidang pariwisatanya, dengan maksud meningkatkan minat kunjungan turis domestik maupun mancanegara. Karena, menurut Roostika (2012), Industri pariwisata mempunyai peranan penting dalam upaya pembangunan dan pengembangan suatu daerah. Persaingan untuk mendapatkan pengunjung dalam industri pariwisata adalah persaingan untuk memenangkan hati dan pikiran konsumen (Morgan \& Pritchard, 2005). Untuk dapat memenangkan persaingan, suatu keunggulan kompetitif sangat diperlukan, karena keunggulan kompetitif adalah inti keberhasilan atau kegagalan suatu organisasi.

Berdasarkan latar belakang diatas maka tujuan penelitian ini adalah mengungkap aspek-aspek keunggulan kompetitif yang dimiliki Kota Batu, mengungkap dan mengkaji strategi yang diterapkan Pemerintah
Kota Batu untuk membangun dan mengkomunikasikan city branding melalui keunggulan kompetitif yang dimiliki dan mengungkap dampak strategi komunikasi yang dilakukan Pemerintah Kota Batu bagi para pengunjung.

\section{METODE}

\section{Desain Penelitian}

Paradigma yang digunakan dalam penelitian ini adalah paradigma kualitatif yaitu penelitian tentang riset yang bersifat deskriptif dan cenderung menggunakan analisis Reinard (2006). Sedangkan pendekatan penelitian yang digunakan pada penelitian ini adalah metode studi kasus terhadap Kota Batu. Fokus studi kasus adalah spesifikasi kasus dalam suatu kejadian baik itu yang mencakup individu, kelompok budaya ataupun suatu potret kehidupan (Creswell, 1998:36).

Lokasi penelitian ini dilakukan pada Badan Perencanaan Pembangunan Daerah (Bappeda) Kota Batu: Jl. Bukit Berbunga No. 13 Sidomulyo Batu, BatuJawa Timur 65317, Dinas Pariwisata dan Kebudayaan Kota Batu: J1. Sultan Agung No. 7B, 65314, Pemerintah Kota Batu Kecamatan Bumiaji (Desa Wisata Kungkuk): Jl. Raya Punten No.17, 65351danKantor Walikota Batu: jl. Panglima Sudirman No. 87 Kota Batu.

Dalam penelitian ini sumber data yang digunakan adalahsumber data primer dansekunder. Sumber data primer dalam penelitian ini berupa keterangan hasil wawancara dengan berbagai narasumber, di antaranya adalah Kepala Bidang Ekonomi Sub Bidang Pariwisata Dan Pertanian Bappeda; Ketua Lembaga Kelompok Masyarakat Desa Kungkuk; Staff Bidang Promosi Dan Pemasaran Produk Wisata Dinas Pariwisata dan Kebudayaan Kota Batu;Ketua Sub Bagian Publikasi Dan Kerjasama Pers; Staf Bagian Pengembangan Sumber Daya Manusia Dinas Pariwisata dan Kebudayaan Kota Batu; maupun 200 pengunjung Kota Batu. Sumber data sekunder berasal dari Kajian City Branding Kota Batu (2013), Batu Milestone, Informasi Potensi Daerah Kota Batu Tahun 2012, Second Edition (2012), Rencana Pembangunan Jangka Menengah Daerah Kota Batu Tahun 20122017 (2012) dan Dinas Pariwisata dan Kebudayaan Kota Batu (2013). Teknik pengumpulan data dalam penelitianya itu melalui wawancara, observasi, dokumentasi dan angket.

Teknik analisis datadalampenelitianiniadalah pengumpulan data (data collection), reduksi data (data reduction), display data (data display) dan 
Verifikasi dan penegasan kesimpulan (conclution drawing and verivication) Miles \& Huberman dalam Sugiyono (2012:334).

\section{HASIL DAN PEMBAHASAN}

\section{Paparan Hasil Penelitian}

\section{Keunggulan Bersaing Kota Batu}

Berdasarkan hasil wawancara dengan berbagai narasumber serta hasil dokumentasi, dapat diperoleh berbagai keunggulan yang dimiliki Kota Batu adalah pertama, keunggulan geografis, berdasarkan hasil wawancara dengan Kepala Bidang Ekonomi Sub Bidang Pariwisata Dan Pertanian Bappeda (w.13/ 03/2014) dan dokumen Batu Milestone, Informasi Potensi Daerah Kota Batu Tahun 2012, Second Edition (2012) dapat diketahui bahwa Kota Batu diuntungkan dengan adannya pegunungan yang mengelilinginya sehingga Kota ini merupakan satusatunya kota di Jawa Timur yang memiliki gunung terbanyak. Gunung Panderman, Gunung Welirang, dan Gunung Arjuno adalah 3 gunung yang telah diakui secara nasional dari sekian banyak gunung.

Kondisi alam yang demikian ini menjadikan Kota Batu memiliki panorama yang indah, udara yang sejuk, dan berpotensi menarik wisatawan dengan objek pariwisata alami. Potensi alami ini dapat dilihat dari jumlah objek wisata yang terbentuk secara alami, contohnya wisata alam Cangar dengan pemandian air panasnya yang bersumber dari mata air pegunungan; air terjun Coban Talun, Coban Rais; Gunung Panderman; wisata alam dan outbond Arboretum; wisata alam keluarga dan sejarah Selecta di mana Candi Ganesha; dan Songgoriti yang juga merupakan wisata alam dan keluarga dengan pemandian air panas.

Selain objek pariwisata yang terbentuk secara alami sebagaimana disebutkan di atas juga terdapat berbagai objek wisata yang menawarkan pengalaman adrenalin yang berlatar belakang pemandangan alam seperti paralayang yang berada di Gunung Banyak; wisata downhill di Gunung Klemuk yang sejak 2004 telah dijadikan lintasan olahraga ekstrem balap sepeda turun bukit; Adventure Cross Runner yang dapat berlokasi di seluruh Wilayah Kota Batu; wisata olahraga rafting yang terletak di Pandanrejo dengan pemandangan hijau yang menyejukkan dan terletak di Desa Torongrejo, menyusuri Kali Brantas dengan melewati tebing yang masih alami sepanjang lebih dari 10 kilometer, pengunjung ditantang keberanian dan adrenalinnya.

\section{Keunggulan Sektor Pertanian}

Komoditi pertanian terdiri dari tanaman pangan, tanaman perkebunan, tanaman holtikultura, tanaman bunga, dan tanaman toga (Batu Milestone, Informasi Potensi Daerah Kota Batu Tahun 2012, Second Edition, 2012).

"....Sektor pertanian terdiri dari sayurmayur, tanaman hias, dan buah-buahan yang dapat tumbuh dengan baik pada wilayah beriklim sejuk; terutama buah apel yang telah lama menjadi salah satu ikon Kota Batu. Atas dukungan kondisi alam yang seperti itu Kota Batu mampu menjadi satu-satunya kota agropolitan mandiri di Jawa Timur. Artinya, tanpa pemerintahpun masyarakat telah lama dapat mengembangkan sektor-sektor ini secara mandiri dengan baik. Di dalam masyarakat sendiri juga telah dibentuk banyak Kelompok Masyarakat (Pokmas) yang bergerak di bidang pertanian dan peternakan" (Bapak Sariono, Ketua Bidang Ekonomi Sub Bidang Pariwisata Dan Pertanian Bappeda, 13/03/2014).

Kemandirian masyarakat atas sektor pertanian yang telah disebutkan di atas dapat diambil contoh dari pernyataan dalam wawancara berikut:

"Sebenarnya, Pokmas ini sudah terbentuk sejak tahun 2007 atas gagasan berbagai pihak perhotelan. Waktu itu, belum ada campur tangan atau bantuan dari pemerintah. Barulah pada 2012 lembaga ini diresmikan oleh pemerintah. Sebagai bentuk kerjasama, pemerintah memberikan bantuan berupa uang untuk dikelola oleh masyarakat (PNPM) dan berupa fasilitas-fasilitas fisik untuk keperluan pariwisata. Sebelum diresmikan oleh pemerintah sekalipun, masyarakat di sini telah mandiri dalam mengelola berbagai potensi yang dimiliki desa ini. Sehingga, banyak wisatawan yang mengunjungi daerah ini untuk berwisata" (Bapak Suwito, Ketua Lembaga Kelompok Masyarakat Desa Kungkuk, 21/03/2014).

Hasil observasi menunjukkan hasil yang sama dengan hasil wawancara, bahwa masyarakat memiliki kemampuan yang sangat baik dalam mengembangkan pertanian karena kondisi alam Kota Batu yang sangat mendukung terhadap berbagai komoditi pertaniannya.

Berbagai objek wisata berbasis pertanian pun telah ada untuk menarik wisatawan mengenal potensi pertanian Kota Batu. Berdasarkan hasil wawancara dengan Staf Bidang Promosi Dan Pemasaran Produk Wisata Dinas Pariwisata Kota Batu (10/04/2014) dan hasil dokumentasi Batu Milestone, Informasi Potensi 
Daerah Kota Batu Tahun 2012, Second Edition, contohnya adalah wisata petik buah Agro Kusuma. Di sini, para pengunjung mendapatkan pengalaman memetik bermacam-macam jenis buah misalkan apel, jeruk, stroberi, jambu, serta bermacam-macam jenis sayuran. Selain itu, terdapat wisata agro pertanian di Desa Punten, Sidomulyo, dan Desa Bumiaji. Selain pengalaman memetik buah dan sayur mayur, pengunjung akan mendapatkan pengetahuan tentang cara budidaya tanaman dan perawatannya. Wisata Agro Bunga Sidomulyo yang merupakan binaan Dinas Pariwisata dan Dinas Pertanian dalam mengembangkan dan pembudidayaan tanaman bunga.

\section{Keunggulan Objek Pariwisata}

Sebagaimana disebutkan di atas, hasil yang didapat dari dokumen Rencana Pembangunan Jangka Menengah Daerah Kota Batu Tahun 2012-2017 mengatakan bahwa Kota Batu memiliki karakteristik kondisi geografis yang mendukung kepariwisataan berbasis alam, atau wisata alam. Selain pariwisata yang keberadaannya diuntungkan oleh kondisi alam maupun pertanian, untuk maksimalisasi keunggulan bersaing Kota Batu dalam bidang pariwisata, ditawarkan juga Objek Daya Tarik Wisata (ODTW) buatan, atau wisata rekreasi, yang tidak melupakan dua basis utama daya tarik Kota Batu serta beberapa diantaranya memiliki ciri khas tersendiri dibandingkan ODTW lain, terutama di Jawa Timur.

Berdasarkan wawancara (24 April 2014) dengan Staf Bidang Promosi Dan Pemasaran Produk Wisata, Dinas Pariwisata Kota Batu, didapatkan contohnya, antara lain Batu Night Spectacular (BNS), merupakan wisata dengan berbagai macam wahana permainan dan pertunjukan lampion-lampion yang hanya dibuka pada malam hari yaitu mulai 16.00 hingga 24.00 WIB. Selain itu, Batu Screet Zoo atau Jatim Park 2, yaitu sebuah wisata edukasi yang mempunyai ciri khas sebagai museum berbagai macam satwa. Pengunjung dapat melihat diorama-diorama hewan dari berbagai belahan dunia. Terdapat pula tempat wisata yang memadukan antara konsep pendidikan dan konsep pariwisata dalam satu waktu, Jatim Park 1. Tempat ini juga dilengkapi dengan Science Stadium yang mempu menampung 300 siswa dan alat peraga ilmu terapan yang diantaranya didukung PLN, Telkom, Rimba Raya, dan sejumlah universitas terkemuka di Jawa Timur. Museum Angkut adalah yang terbaru. Tempat wisata edukasi yang baru launching tahun 2013 ini menghadirkan berbagai alat transportasi kuno dan modern dari seluruh belahan dunia dan dilengkapi dengan tampilan kota asalnya.

Mengenai pengembangan keunggulan pariwisata Kota Batu, Kepala Bidang Ekonomi Sub Bidang Pariwisata Dan Pertanian Bappeda (13/03/2014) mengatakan:

"Dalam rangka mewujudkan visi Kota Batu, kami memiliki suatu program yang disebut 'Batu Go Organik”, dimulai dari tahun 2012, yang golnya adalah pada tahun 2017 nanti. Salah satu implementasinya adalah dibangunnya objek pariwisata baru tiap tahunnya. Contoh yang telah ada adalah Museum Angkut yang baru lauching tahun 2013 kemarin; kemudian, rencananya, tahun berikutnya akan ada Kereta Gantung; lalu Asean Culture Park, dan seterusnya" (Bapak Sariono, Kepala Bidang Ekonomi Sub Bidang Pariwisata Dan Pertanian Bappeda, 13/03/2014).

Untuk mempertahankan keunggulan dalam aspek pariwisata ini,Kepala Bidang Ekonomi Sub Bidang Pariwisata Dan Pertanian Bappeda (13/03/2014) menjelaskan bahwa bukan hanya dari kepemerintahan saja yang berbasis pariwisata. Akan tetapi, seluruh tingkat pendidikan yang ada di Kota Batu diwajibkan untuk menerapkan kurikulum kepariwisataan bagi siswa siswinya sebagai usaha untuk mempersiapkan kemampuan SDM Kota Batu di masa depan.

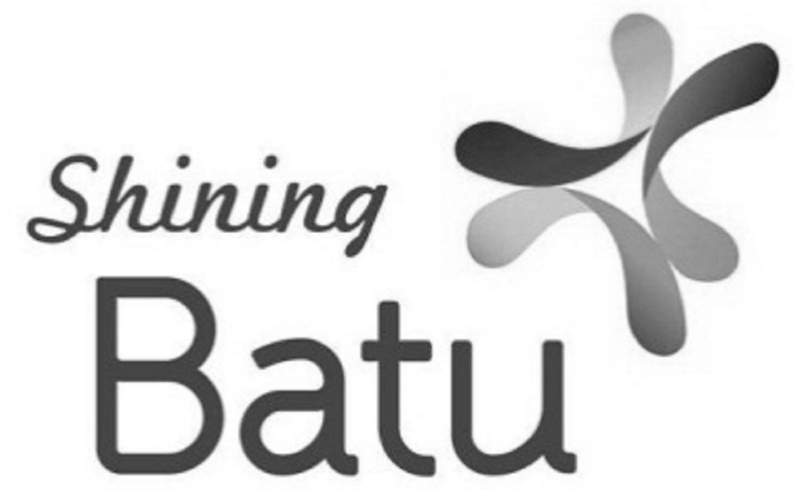

Gambar 1. Logo Shining Batu

Berdasarkan hasil dokumentasi diperoleh makna yang terkandung dalam logo Shining Batu (Kajian City Branding Kota Batu, 2013): 1) Menggambarkan bahwa Kota Batu adalah daerah yang nyaman, aman, tentram, dan makmur; 2) Kota Batu adalah daerah yang gemah ripah loh jinawi secara ekonomi dan memiliki jiwa kebersamaan yang tinggi antar warga Kota Batu; 3) Kota Batu memiliki hubungan yang harmonis antara warga dan pemerintahnya. Serta memiliki relationship yang kuat antar seluruh stakeholder; 4) Merupakan gabungan dari tiga citra Kota Batu, 
yaitu pariwisata (merah), pertanian (hijau), dan pendidikan (biru); 5) Garis lengkung berwarna biru juga merupakan representasi hubungan vertikal manusia kepada Tuhan; 6) Garis merah-oranye menggambarkan hubungan horisontal antar sesama manusia; 7) Garis lengkung hijau menggambarkan hubungan manusia kepada sesama makhluk ciptaan Tuhan (alam) dan 8) Ketiga garis tersebut saling bersinergi membentuk bintang tiga sisi merupakan penggambaran bahwa Kota Batu merupakan kota impian.

Berdasarkan hasil dokumentasi pada Kajian City Branding Kota Batu (2013), dalam pembentukan Shining Batu ada beberapa tahapan yang dilalui, antara lain: pertama, mengidentifikasi keunggulan atau potensi yang dimiliki. Ada dua jenis keunggulan yang berhasil diidentifikasi oleh Pemerintah Kota Batu yang disebut dengan tangible asset dan intangible asset. Yang dimaksud dengan tangible asset adalah seluruh potensi-potensi yang dimiliki Kota Batu, baik itu potensi sumber daya alam maupun potensi sumber daya manusia dan budaya. Sedangkan intangible asset adalah persepsi yang terbentuk di dalam benak target audience terhadap Kota Batu. Kedua, menjabarkan visi Kota Batu yang disebutkan dalam Tri Asa-mewujudkan Kota Batu sebagai sentra pertanian, sentra pariwisata, dan sentra pendidikan di bidang pariwisata - untuk menciptakan parameter tertentu yang harus dicapai sehingga proses pengembangan brand Kota Batu akan lebih terarah. Dari hasil riset ini dibentuklah positioning Kota Batu: "Kota Wisata Modern Berbasis Alam".

Ketiga, memperkenalkan brand Kota Batu, yakni Shining Batu, yang dilakukan pada tahun 2013. Dalam awal-awal tahun pelaksanaannya, tujuan utama dari program city branding Kota Batu ialah meletakkan pondasi yang kokoh untuk penerapan program di tahun-tahun berikutnya.Keempat, melakukan kerjasama yang bersinergi antar berbagai elemen kota. Posisi pemerintah kota adalah sebagai inisiator program, sedangkan yang kemudian bergerak secara aktif untuk mewujudkan program ini adalah seluruh lapisan masyarakat danterakhir mengevaluasi dan memonitor melalui ketua berbagai Kelompok Masyarakat yang menjadi perantara antara pemerintah dengan masyarakat Kota Batu.

Sementara itu, untuk mengetahui strategi mengkomunikasikan Shining Batu, peneliti melakukan pada Staf Bidang Promosi dan Pemasaran Produk Wisata, Dinas Pariwisata Kota Batu (w.10/04/2014).

Berbagai keunggulan Kota Batu direalisasikan dalam program pemerintah yaitu Kota Wisata Batu
(KWB). Program Paket-Paket Wisata dan Promosi melalui Satuan Kerja Perangkat Daerah (SKPD) Dinas Pariwisata dan Kebudayaan Kota Batu, Bidang Promosi. Bentuk-bentuk Paket Wisata antara lain seperti petik apel, paket wisata petik sayur, paket wisata petik stroberi, paket wisata edukasi pertanian, paket wisata edukasi peternakan, dan paket wisata outbond seperti wisata alam, rafting, dan sebagainya.

Sedangkan bentuk promosi bisa melalui penyelenggaraan event yang bersifat insidentil, seperti live show artis-artis ibu kota (NOAH, Dewa, D'Masif, dsb.) maupun event tahunan. Event-event tersebut adalah Gebyar Nusantara yang mana di dalamnya terdapat parade dan live show berbagai budaya dari 10 provinsi di Indonesia (Jawa Timur, Bali, Papua, Aceh, Sumatera Barat, Kalimantan Barat, Kalimantan Timur, Sulawesi Utara, Sulawesi Selatan, Yogyakarta, DKI Jakarta, Jawa Barat); kemudian event Batu Travel Mart (BTM) yang diselenggarakan di Kota Batu dengan mendatangkan travel agent dari seluruh Indonesia maupun dari luar negeri; selain itu juga terdapat International Batu Open Paragliding (paralayang); Batu Flora Festival (BFF) yang mana salah satu acaranya adalah mendatangkan berbagai mobil hias;Batu Night Criterium atau event balap sepeda di malam hari yang melewati jalan penuh tanjakan.

Bentuk promosi yang dilakukan juga dengan cara berpartisipasi sebagai peserta Majapahit Travel Fair (MTF) di Surabaya yang diadakan setiap tahun. Acara tersebut diselenggarakan oleh Dinas Kebudayaan Dan Pariwisata Provinsi Jawa Timur. Promosi juga dilakukan dengan cara mempublikasikan setiap event dan juga potensi Kota Batu melalui website (www. shining-batu.com).

Keterangan di atas sudah mencakup aspek-aspek yang menurut Kavataris (2004) harus dikomunikasikan dalam city branding. Empat aspek pertama adalah landscape strategies, behaviour, organizational structure, dan infrastructure. Sedangkan aspek kedua berupa publikasi, periklanan, public relation, desain grafis, slogan, dan lain-lain.

\section{Dampak Eksplorasi Keunggulan Kompetitif Kota Batu}

Untuk mengetahui dampak eksplorasi keunggulan kompetitif yang dimiliki Kota Batu serta usaha untuk mengkomunikasikannya dapat diketahui dari jumlah perkembangan kunjungan dari tahun ke tahun, jumlah hotel yang memadai sebagai fasilitas bagi para 
pengunjung, dan data angket yang disebarkan peneliti terhadap para pengunjung untuk mengetahui objek wisata manakah yang paling diminati oleh pengunjung — karena masing-masing objek wisata mewakili keunggulan kompetitif Kota Batu.

Berdasarkan hasil dokumentasi pada Dinas Pariwisata Dan Kebudayaan Kota Batu (2013) menyebutkan, pasar wisatawan mancanegara yang berkunjung ke Kota Batu pada tahun 2012, indikasi tempat menginap masih didominasi negara-negara di kawasan Eropa, Asia Timur, Asia Tenggara. Kawasan Eropa paling banyak adalah Belanda, sedang Asia Timur adalah Jepang dan Cina.Untuk kawasan Asia Tenggara adalah Malaysia dan Sigapura. Sedangkan wisatawan nusantara yang berkunjung berjumlah 451.959 . wisatawan nusantara dari Jawa Timur masih mendominasi kunjungan wisatawan nusantara ke Kota Batu. Wisatawan dari Jawa Tengah memberikan kontribusi kunjungan cukup banyak sekitar 234.716 kunjungan. Disusul wisatawan asal DKI Jakarta sekitar 15.487 kunjungan. Wisatawan dari daerah Jawa Barat, Lampung, Kalimantan Timur, dibanding dengan ketiga daerah tersebut di atas tingkat kunjungan pada tahun 2012 cukup merata.

Kunjungan wisatawan juga dapat dilihat dari jumlah kunjungan pada ODTW yang ada. Pada tahun 2012 total kunjungan mencapai 1.427.035. Untuk perbandingan, kunjungan wisatawan ODTW pada tahun 2011 adalah 1.961 .559 , pada tahun 2010 2.140.866, dan pada tahun 2009 mencapai 3.091.031

Jumlah kunjungan ke ODTW Kota Batu yang terus menerus menurun di atas tidak sejalan dengan pembangunan ODTW yang terus menerus berkembang dari tahun ke tahun. Berdasarkan wawancara terhadap Staf Bagian Pengembangan Sumber Daya Manusia (PSDM) Dinas Pariwisata dan Kebudayaan Kota Batu (25/06/2014) menjelaskan mengapa hal itu terjadi. Turunnya jumlah pengunjung pada ODTW yang dilaporkan di atas dapat dipengaruhi oleh beberapa hal, di antaranya adalah ketidak jujuran pihak manajemen beberapa ODTW untuk melaporkan jumlah kunjungan yang sebenarnya disebabkan keengganan mereka terhadap penarikan pajak seiring jumlah pengunjung, adanya bencana alam seperti tanah longsor pada beberapa ODTW dan kedatangan para pengunjung ke Kota Batu tidak selalu bertujuan untuk berwisata; beberapa diantaranya berbisnis, bertugas, ataupun lain-lain.

Apa yang dikatakan Staf Bagian Pengembangan Sumber Daya Manusia (PSDM) Dinas Pariwisata dan Kebudayaan Kota Batu di atas, dapat dibuktikan dengan kunjungan terhadap hotel yang terus menerus meningkat. Pada 2009 jumlah kunjungan sebanyak 415.332; tahun 2010 meningkat sebesar 43,01\% atau sebanyak 417.266 tamu; pada tahun 2011 mengalami penurunan sebesar $6.10 \%$ atau sebanyak 337.477 ; dan tahun 2012 meningkat menjadi 462.688 kunjungan atau sebesar $1,96 \%$. Tidak setiap pengunjung yang menginap di hotel bertujuan untuk mengunjungi tempat-tempat wisata.

Ketersediaan penginapan atau hotel merupakan salah satu aspek yang penting dalam meningkatkan daya saing daerah. Dikarenakan banyaknya ODTW yang ada di Kota Batu mendatangkan banyak pengunjung dan wisatawan maka keberadaan penginapan/hotel juga perlu dikembangkan. Berdasarkan dokumentasi pada rencana pembangunan jangka menengah daerah kota batu tahun 2012-2017 dapat diketahui perbandingan jumlah hotel antara tahun 2012 dengan 2008. Pada tahun 2008, total jumlah hotel yang ada di Kota Batu adalah 59 hotel dengan jumlah 2571 kamar. Jumlah ini bertambah pada tahun 2012, yakni ada 60 hotel dengan 2764 jumlah kamar.

Berdasarkan hasil survey kepada 200 orang pengunjung $3 \%$ diantaranya berkunjung ke Kota Batu untuk bertugas, $1,5 \%$ untuk berbisnis, dan sisanya $95,5 \%$ untuk berwisata atau berlibur.

Responden yang bertujuan wisata, $90 \%$ diantaranya memilih wisata rekreasi (Jatim Park, Batu Screet Zoo, Museum Angkut, BNS, dan semisalnya); 9,5\% mengunjungi wisata alam (Coban Rondo, Cangar, wisata Agro, wisata petik buah, dan lain-lain); dan $0,5 \%$ mengunjungi wisata adrenalin atau olah raga (paralayang) sebagai pilihan utama untuk berwisata. Sedangkan untuk tempat wisata yang menjadi pilihan cadangan untuk diunjungi (secondary choice) juga masih didominasi oleh wisata rekreasi yaitu sebanyak 94\%; sebanyak 5\% untuk wisata alam; $0,5 \%$ wisata adrenalin atau olah raga; dan 0,5\% desa wisata (Desa Wisata Kungkuk).

Kebanyakan pengunjung memilih untuk tidak menginap untuk pulang atau menuju kota lain yaitu sebanyak $82 \%$. Untuk pengunjung yang menginap $8,5 \%$ memilih untuk menginap di hotel; 5,5\% menginap di villa; dan $4 \%$ menginap di tempat tinggal saudara. Oleh karena itu, keberadaan penginapan ataupun hotel sangat penting. Data statistik perkembangan wisatawan yang menginap di Kota Batu pada dokumen Dinas Pariwisata dan Kebudayaan Kota Batu melaporkan jumlah kunjungan tamu pada semua hotel di Kota Batu terus meningkat, sebagaimana yang telah disebutkan di atas. 
Selain itu, peneliti juga menanyakan pengetahuan pengunjung mengenai Shining Batu. Dari semua pengunjung yang ditanya mengaku tidak mengetahui Shining Batu. Mereka justru akrab dengan sebutan Kota Wisata Batu.

\section{Pembahasan}

\section{Keunggulan Bersaing Kota Batu}

Tiga aspek keunggulan yang telah disebutkan di atas merupakan beberapa hal yang tidak dimiliki atau hanya sebagian kecil saja yang dimiliki oleh kota-kota lain, terutama di Jawa Timur. Oleh karenanya, hal ini dapat disebut sebagai keunggulan kompetitif bagi Kota Batu. Karena, sesuai dengan yang dinyatakan oleh Grant (1991); Porter (1993); David (2006); Wheelen \& Hunger (2004) keunggulan kompetitif adalah ketika sebuah perusahaan memiliki keterbedaan yang tidak dimiliki pesaingnya. Dalam konteks ini dapat diambil contoh objek wisata yang unik dan berbeda dari yang dimiliki kota lain adalah Museum Angkut, Agrowisata, BNS, dan Batu Screet Zoo, atau dapat melakukan sesuatu yang tidak dapat dilakukan dengan baik oleh para pesaingnya sehingga perusahaan tersebut dapat memperoleh keuntungan yang lebih tinggi daripada pesaingnya, seperti kemampuan masyarakat Kota Batu dalam mengelola potensi tempat tinggalnya dan penerapan kurikulum berbasis pariwisata.

Keunggulan bersaing kota Batu mencerminkan kemampuan Kota Batu dalam mengenali atau mengidentifikasi, mengeksplorasi, dan mengolah dengan baik berbagai keunikan atau keunggulan yang dimilikinya; antara lain dalam aspek geografis, pertanian, dan pariwisatanya. Kemampuan tersebut adalah salah satu cara untuk mempertahankan keunggulan kompetitifnya secara berkelanjutan. Sesuai dengan yang dikemukakan Grant (1991) tentang lima langkah untuk meraih keunggulan bersaing melalui sumber daya yang dimiliki

Sementara itu, Wheelen \& Hunger (2004) mengatakan terdapat dua karakter yang menentukan keunggulan kompetitif yang berkelanjutan: daya tahan kompetensi inti dari keusangan serta daya tahan dari pesaing yang ingin meniru. Artinya, selama Kota Batu dapat mempertahankan kompetensi intinya, yang dicerminkan antara lain oleh kemandirian masyarakatnya dalam mengelola pertanian dan potensi di setiap daerahnya serta penerapan kurikulum kepariwisataan di tiap tingkat pendidikan; dan kondisi geografisnya yang menguntungkan selalu dijaga dan dilestarikan dengan baik, maka kemungkinan besar keunggulan kompetitif yang dimiliki Kota Batu akan berkelanjutan atau bertahan.

Selain potensi masyarakat dan sistem pendidikan yang harus selalu konsisten guna mempertahankan keunggulan kompetitif agar berkelanjutan, kondisi geografis dan potensi alam juga harus dilestarikan dan dijaga sebagai bentuk syukur atas anugerah yang telah diberikan Tuhan tersebut. Dalam Surat Yasin ayat 3335 Allah berfirman:

"Dan suatu tanda (kekuasaan Allah yang besar) bagi mereka adalah bumi yang mati. Kami hidupkan bumi itu dan Kami keluarkan dari padanya biji-bijian, maka daripadanya mereka makan. Dan Kami jadikan padanya kebun-kebun kurma dan anggur dan kami pancarkan padanya beberapa mata air, supaya mereka dapat makan dari buahnya, dan dari apa yang diusahakan oleh tangan mereka. Maka mengapakah mereka tidak bersyukur?"(QS. Yasin:33-35).

Di samping itu, juga karena Tuhan menjanjikan untuk melipat gandakan anugerahnya jika disyukuri dan mengancam orang yang tidak bersyukur. Sebagaimana tertera dalam Alquran Surat Ibrahim ayat 7:

"Dan (ingatlah juga) tatkala Tuhanmu memaklumkan: Sesungguhnya jika kamu bersyukur pasti Kami akan menambah (nikmat) kepadamu, dan jika kamu mengingkari (nikmatKu) maka sesungguhnya azabKu sangat pedih."(QS. Ibrahim:7)

Oleh sebab itu, berdasarkan nilai-nilai Islam, merupakan hal yang sangat penting bagi pemerintah maupun masyarakat Kota Batu untuk selalu konsisten dalam meningkatkan kemampuan dalam mengelola potensi yang dimiliki dan selalu menjaga kelestarian alam dan lingkungannya.

Dari laporan data yang telah dibahas di atas, jika merujuk strategi generik (generic strategies) Porter, dapat dilihat bahwa Kota Batu menggunakan strategi diferensiasi untuk mencapai keunggulan kompetitif. Menurut Porter (1994), strategi memungkinkan organisasi untuk mendapatkankeunggulan kompetitif dari tiga dasar: kepemimpinan harga, diferensiasi, dan fokus. Wheelen \& Hunger (2004) mengemukakan disebut "generic" karena strategi-strategi tersebut dapat digunakan untuk berbagai jenis perusahaan, bahkan untuk organisasi non-profit sekalipun. Ajaran Porter tentang strategi generik untuk mencapai keunggulan bersaing ini terdiri dari kepemimpinan biaya, diferensiasi, dan fokus (Prasetya, Rahardja, \& Hidayati, 2007). Aaker (1989) mengatakan bila perusahaan kemudian mampu menciptakan keunggulan melalui 
salah satu dari ketiga strategi generik yang dikemukakan oleh Porter tersebut, maka keunggulan bersaing akan dapat diraih.

Beberapa tempat wisata yang ada, sebagian besar adalah tempat wisata yang unik atau berbeda dari tempat-tempat wisata di kota-kota lain, terutama di Jawa Timur. Seperti: Museum Angkut, Batu Screet Zoo, BNS, Kusuma Agro Wisata, Paralayang, yang akan datang kereta gantung, dan lain sebagainya. Porter (1994) mengatakan, dalam strategi diferensiasi perusahaan berusaha menjadi unik dalam industrinya di sepanjang beberapa dimensi yang secara umum dihargai oleh pembeli. Menurut David (2006), diferensiasi tidak menjamin keunggulan kompetitif, khususnya jika produk standar cukup memenuhi kebutuhan konsumen atau imitasi cepat dapat dilakukan oleh pesaing. Ia menjelaskan strategi diferensiasi yang berhasil memungkinkan perusahaan untuk menetapkan harga yang lebih tinggi untuk produknya.

Berdasarkan hasil wawancara, dokumentasi, maupun observasi yang telah dilaporkan di atas, dapat diketahui bahwa Kota Batu selalu melakukan pembangunan dalam sektor pariwisata yang pada akhirnya hal ini menjadi keunggulan tersendiri bagi Kota Batu. Sebagaimana yang dikatakan David (2006), salah satu keunggulan bersaing adalah kemampuan melakukan sesuatu yang tidak dapat dilakukan dengan baik atau bahkan tidak mampu dilakukan pesaingnya. Demikian ini, Kota Batu juga diuntungkan oleh keunggulankeunggulan lain, yang telah dijelaskan, yang tidak dimiliki pesaingnya.

\section{Strategi Membangun dan Mengkomunikasikan City BrandKota Batu}

Kesimpulan sementara dapat dinyatakan bahwa ada beberapa strategi yang dilakukan pemerintah untuk mengkomunikasikan keunggulan-keunggulan yang dimiliki Kota Batu. Pemerintah mengadakan Program Paket Wisata dan Promosi melalui Satuan Kerja Perangkat Daerah (SKPD) Dinas Pariwisata dan Kebudayaan Kota Batu, Bidang Promosi, antara lain: pertama, bentuk paket wisata, seperti:Paket Wisata Petik Apel, Paket Wisata Petik Sayur, Paket Wisata Petik Stoberi, Paket Wisata Edukasi Pertanian, Paket Wisata Edukasi Peternakan dan Paket Wisata Outbond; Wisata Alam; Rafting; Tubing; dan lain sebagainya.

Kedua, Bentuk Promosi, melalui penyelenggaraan event-event tahunan maupun insidentil, misalnya Gebyar Nusantara: parade dan live show berbagai budaya dari 10 provinsi di Indonesia 16-17 Mei 2014 (Jawa Timur, Bali, Papua, Aceh, Sumatera Barat, Kalimantan Barat, Kalimantan Timur, Sulawesi Utara, Sulawesi Selatan, Yogyakarta, DKI Jakarta, Jawa Barat), publikasi setiap event dan potensi si website www.shining-batu.com, partisipasi peserta di Majapahit Travel Fair (MTF) Surabaya setiap tahu yang diselenggarakan Dinas Kebudayaan dan Pariwisata Provinsi Jawa Timur, Batu Travel Mart (BTM) di Kota Batu dengan mendatangkan Travel Agent dari seluruh Indonesia maupun dari luar negeri, International Batu Open Paragliding (paralayang), Batu Flora Festival (BFF): mobil hiasdanBatu Night Criterium: event balap sepeda ekstrim di malam hari.

Selain berbagai event pemerintah juga mengkomunikasikannya melalui website, majalah-majalah, kolom khusus di koran Radar Malang, televisi lokal, radio, berbagai merchandise, billboard maupun baliho di berbagai area dan jalanan di Kota Batu, serta melalui bandara Abdurrahman Saleh di Malang dan Juanda di Surabaya.

\section{Dampak}

Berdasarkan persepsi pengunjung yang diketahui dari penyebaran angket, Jika dilihat dari visi Kota Batu yang ingin menjadi kota sentra pertanian organik berbasis pariwisata serta usaha pemerintah yang barubaru ini lebih fokus kepada pengembangan Desa Wisata, hal ini tentu menjadi sebuah permasalahan tersendiri. Sebab, persepsi masyarakat terhadap Kota Batu telah mengalami pergeseran dan tidak sejalan dengan visi Kota Batu. Di balik keberhasilan Kota Batu atas maraknya pembangunan di sektor pariwisata membuat citra Kota Batu yang semula identik sebagai kota wisata alam dan agrowisata, kini telah bergeser menjadi sebagai kota wisata rekreasi.

Persepsi yang muncul dibenak konsumen mengenai citra dari sebuah tempat tujuan, menurut Situmorang (2008), merupakan salah satu tantangan yang ada dalam menyusun city branding. Untuk itu, ada dua faktor utama yang menurut Baloglu dan McClearly (1999) harus diperhatikan. Dua faktor tersebut adalah faktor stimulus dan faktor pribadi. Faktor stimulus bersumber dari dorongan eksternal dan objek fisik serta pengalaman sebelumnya. Sedangkan faktor personal, adalah karakteristik (sosial dan psikologis) seseorang. Menurut Kotler \& Keller (2009), elemen merek (brand element) dapat mengidentifikasi dan mendiferensiasikan merek dari yang lain. Terdapat enam kriteria utama sebagaimana dijelaskan di bab II. 


\section{KESIMPULAN DAN SARAN}

\section{Kesimpulan}

Berdasarkan hasil penelitian yang dilakukan terhadap Kota Batu, terdapat beberapa aspek yang menurut peneliti dapat disebut sebagai keunggulan kompetitif Kota Batu, antara lain pada aspek geografis, sektor pertanian, dan objek pariwisata yang dimilikinya. Ketiga aspek tersebut memiliki keterkaitan erat yang saling melengkapi. Sehingga, pada akhirnya, menjadi keuntungan tersendiri bagi Kota Batu yang dapat mendukung visi Kota Batu sebagai sentra pertanian organi berbasis kepariwisataan internasional.

Seluruh keunggulan atau potensi ini dicerminkan melalui Shining Batu yang merupakan city branding Kota Batu.Adapun tahap-tahap yang dilakukan pihakpihak tersebut dalam proses penciptaan dan pengembangan city branding Kota Batu ini sesuai dengan tahapan yang disarankan oleh Morgan \& Pritchard (2004). Untuk mengkomunikasikannya, Bagian Promosi Dinas Pariwisata dan Kebudayaan Kota Batu melakukan berbagai strategi komunikasi, antara lain: bantuk paket wisata, bentuk promosi dan even yang bersifat insidentil. Selain berbagai event pemerintah juga mengkomunikasikannya melalui website, majalahmajalah, kolom khusus di koran Radar Malang, televisi lokal, radio, berbagai merchandise, billboard maupun baliho di berbagai area dan jalanan di Kota Batu, serta melalui bandara Abdurrahman Saleh di Malang dan Juanda di Surabaya.

\section{Saran}

Bagi pemerintah Kota Batu agar melakukan monitoring dan evaluasi yang lebih intensif karena pada kenyataannya Shining Batu tidak dikenal oleh pengunjung dan adanya pergeseran persepsi konsumen yang tidak sesuai dengan visi misi awal Kota Batu. Hal ini juga merupakan masalah dalam penyusunan city branding maupun proses komunikasi yang dilakukan oleh pemerintah. Bagi peneliti selanjutnya agar menambahkan analisis SWOT untuk mengetahui strategi competitive advantage.

\section{DAFTAR RUJUKAN}

Ardialisa, F., Hermawan, A., Chozin, M.A. 2012. Analysis On Sustainability Of Tourism Business, Jurnal Manajemen \& Agribisnis.

Baloglu, S., \&McClearly, K.W. 1999. Model of Destination Image Formation, Annuals of Tourism Research, Vol. 26, No. 4
Blain, C., Levi, E.S., \& Ritchie, J.R. 2005. Destination Branding: Insight And Practices from Destination Management Organizations, Journal of Travel Research.

Botha, C., Cromption, J., \& Ki, S. 1999. Developing ARevised Competitive Strategy for Sun/Lost City, South Africa. Journal of Travel Research.

Chan, W.K., \& Renee, M. 2005. Blue Ocean Strategi (Strategi Samudera Biru) Terjemahan Satrio Wahono. Jakarta: Serambi Ilmu Semesta.

Creswell, J.W. 1998. Qualitative Inquiry and Research Design; Choosing Among Five Tradition. London: SAGE Publication.

David, Fred, R. 2006. Manajemen Strategis, Edisi Sepuluh, Jakarta: Salemba Empat.

Freire, J.R. 2007. 'Local People a Critical Dimension For Place Brands'. Journal of Brand Management.

Gardyn, R. 2002. Packaging Cities; American Demographics, 01-01-2002, Packaging Cities Volume: 24: IISSN: 0163408901-01-2002.

Ginting, P., \& Situmorang, S.H. 2010. Filsafat Ilmu dan Metode Riset. Medan: USU Press.

Grant, R.M. 1991. The Resource-Based Theory Of Competitive Advantage: Implication For Strategy Formulation, California Management Review (Spring 1991).

Hadi, A., \& Haryono. 1998. Metodologi Penelitian Pendidikan II. Bandung: Pustaka Setia.

Hall, D. 2002. Branding And National Identity: The Case of Central and Eastern Europe, Destination Branding: Creating The Unique Destination Proposition (2002, 1st Edt). Elseiver Ltd. Oxford.

Handoko, T.H. 2000. Manajemen Personalia dan Sumberdaya Manusia, Edisi II. Yogyakarta: Penerbit BPFE.

Keller, K.L. 1998. Strategic Brand Management: Building, Measuring, and Managing Brand Equity. Upper Saddle River. New Jersey: Prentice Hall.

Kotler, P. 2004. Marketing Insight From A to Z. Jakarta: Erlangga.

Menone. 2011. Kota Wisata Batu (Sejarah), http://menone. wordpress.com/2011/06/19/kota-wisata-batu-sejarah/ \#more-5124.

Moilanen, T., \& Rainisto, S. 2009. How To Brand Nations, Cities And Destinations, A Planning Book For Place Branding, USA: Palgrave Macmillan.

Morgan, N., Pritchard, A., Pride, R. 2004, Destination Branding: Creating The Unique Destination Proposition, Second Edition, London:Elseiver ButterworthHeinemann.

Morgan, N., \& Pritchard, A. 2005. Promoting Niche Destination Brands: Case Studies of New Zealand And Wales. Journal of Promotion Management, Vol. 12.

Porter, M.E. 1994. Keunggulan Bersaing. Jakarta: Bina Rupa Aksara.

Porter, M.E. 1998. Strategi Bersaing. Tangerang: Karisma Publishing Group. 
Prasetya, H., Rahardja, E., Hidayati, R. 2007. Membangun Keunggulan Kompetitif melalui Aliansi Stratejik Untuk Meningkatkan Kinerja Perusahaan (Studi Kasus pada PT Pos Indonesia Wilayah VI Jateng Dan DIY), Jurnal Studi Manajemen \& Organisasi, Vol. 4 No. 2.

Puspitarini, M. 2014. ITS Siap Kembangkan Kereta Gantung sebagai IconKotaBatu,http://kampus. okezone.com/read/2014/01/23/373/930843/its-siapkembangkan-kereta-gantung-sebagai-icon-kota-batu.

Rainisto, S.K. 2003. Success Factors of Place Marketing: A Study of Place Marketing Practicies in Northern Europe and The United States, Doctoral Dissertations, Helsinki University of Technology, Institute of Strategy and International Business.

Reinard, J.C. 2006. Communication Research Statistics, SAGE, ISBN0-7619-2987-8 ISBN978-0-7619-2987-1.

Roostika, R. 2012. Citra Merek Tujuan Pariwisata dan Perilaku Wisatawan: Yogyakarta sebagai Daerah Tujuan Wisata, Jurnal Manajemen dan Akuntansi.
Situmorang, S.H. 2008. Destination Brand: Membangun Keunggulan Bersaing Daerah. Jurnal Perencanaan \& Pengembangan Wilayah, Vol.4, No.2.

Situmorang, S.H. 2008. Destination Brand: Membangun Keunggulan Bersaing Daerah. Jurnal Perencanaan \& Pengembangan Wilayah, Vol.4, No.2.

Sugiyono. 2008. Memahami Penelitian Kualitatif. Bandung: Alfabeta.

Sugiyono. 2012. Metode Penelitian Kuantitatif dan Kualitatif $R \& D$. Bandung: Alfabeta.

Sutopo. 2011. Lebih Dekat Dengan Apel Indonesia, http:/ /kpricitrus.wordpress.com/2011/04/04/kriteriakesesuaian-lahan-untuk-tanaman-apel-di-iklimtropika/

Wheelen, T.L., \& Hunger, J.D. 2004 Strategic Management And Business Policy 9th Edition. New Jersey: Pearson Education International. 